\title{
MANAJEMEN SOFT SKILL ENTREPRENEURSHIP PESANTREN (Studi Kasus Pesantrem PERWIRA ABA Klaten, Jawa Tengah)
}

\author{
Sarwadi, Dhian Marita Sari \\ Dosen Sekolah Tinggi Ilmu Tarbiyah Madani Yogyakarta \\ Email : sarwadis@gmail.com, DhianFirdausa@gmail.com
}

\begin{abstract}
Abstrak
Pesantren adalah pendidikan tertua di Indonesia. Karena kematanganya dalam dunia pendidikan, pesantren selalu beradaptasi disetiap masa. Perubahan selalu dilakukan sebagai bentuk respon terhadap kebutuhan masyarakat yang sedang dan akan dihadapi. Salah satu inovasi dari pesantren yang penulis teliti adalah dengan adanya pesantren Entrepreneurship di daerah klaten jawa tengah. Entrepreneurship bukan sekedar menjadi aktifitas tambahan sebagaimana yang lazim diberbagai lembaga pendidikan. Akan tetapi entrepreneurship memang dijadikan sebagai visi dari pesantren tersebut. Sebagai komitmen mewujudkan cita-cita entrepreneur maka manajemen pengembangan soft skillnya pun disusun dalam bentuk kurikulum sampai santri lulus betul betul menjadi seorang entrepreneur. Soft skill sebagai kebutuhan primer kaum entrepreneur disajikan dalam sebaran kurikulum dari awal masuk pesantren sampai santri lulus.
\end{abstract}

\section{Kata kunci : Pesantren, manajemen, softskill}

\begin{abstract}
The author found the management's urgency in developing soft skills entrepreneurship to determine the success of the vision of forming a satripreneur from a boarding school graduate. Second, mental development of entrepreneurship alone is not enough if there is no spiritual cultivation. Third, the beginning of curriculum planning and management entrepreneurship. Among the developments that must be carried out by the pesantren are the development of pesantren human resources, the development of pesantren communication, the economic development of pesantren, and the development of pesantren information technology. Then the
\end{abstract}


pattern of thinking and orientation of life to the development of entrepreneurship is an important thing to start building.

\section{Keywords: entrepreneurship, human development, life orientation}

\section{A. Pendahuluan}

Pesantren merupakan bagian dari pendidikan nasional yang telah ada jauh sejak pra kemerdekaan dan bahkan disinyalir sebagai lembaga pendidikan yang memiliki kekhasan, keaslian, Indonesia. Pesantren juga dianggap sebagai lembaga pendidikan Islam tertua yang tidak diragukan lagi peranannya bagi perkembangan Islam nusantara. ${ }^{1}$ Sebagai bagian lembaga pendidikan nasional, kemunculan pesantren dalam sejarahnya telah berusia ratusan tahun, dan disinyalir sebagai lembaga yang memiliki kekhasan, keaslian (indegeneous) Indonesia. ${ }^{2}$ Sebagai institusi indegeneous, pesantren muncul dan terus berkembang dari pengalaman sosiologis masyarakat di sekitar lingkungannya. Akar kultural ini barangkali sebagai potensi dasar yang telah menjadikan pesantren dapat bertahan, dan sangat diharapkan baik bagi masyarakat maupun pemerintah.

Pesantren lahir Sebagai sebuah institusi budaya yang lahir atas prakarsa dan inisiatif (tokoh) masyarakat dan bersifat otonom, sejak awal, berdirinya pesantren merupakan potensi strategis yang ada di tengah kehidupan sosial masyarakat. Kendati kebanyakan

${ }^{1}$ Habib Thoha, Kapita Selekta Pendidikan Islam, (Yogyakarta : Pustaka Pelajar, 1996), hlm 41.

2 Nurcholish Madjid, Bilik-Bilik Pesantren Sebuah Potret Perjalanan, (Jakarta: Paramadina, 1997), hlm. 3. 
pesantren hanya memposisikan dirinya sebagai institusi pendidikan dan keagamaan, namun sejak tahun 1970-an beberapa pesantren telah berusaha melakukan reposisi dalam menyikapi berbagai persoalan sosial masyarakat, seperti ekonomi, sosial, dan politik.

Pesantren terus bermetamorfosis dan menunjukan perilaku adaptifnya, sehingga masyarakat tidak berpindah ke lain hati dan meninggalkanya. Pesantren dengan berbagai harapan dan predikat yang dilekatkan kepadanya, sesungguhnya berujung pada tiga fungsi utama yang senantiasa diembannya, yaitu: (1) sebagai pusat pengkaderan pemikir-pemikir agama (centre of exellence), (2) sebagai lembaga yang mencetak sumber daya manusia (human resource), (3) sebagai lembaga yang mempunyai kekuatan melakukan pemberdayaan pada masyarakat (agent of development). ${ }^{3}$ Selain ketiga fungsi tersebut pesantren juga dipahami sebagai bagian yang terlibat dalam proses perubahan sosial (social change) di tengah perubahan yang terjadi.

Dalam keterlibatannya dengan peran, fungsi, dan perubahan yang dimaksud, pesantren memegang peranan kunci sebagai motivator, inovator, dan dinamisator masyarakat. Hubungan interaksionis-kultural antara pesantren dengan masyarakat menjadikan keberadaan dan kehadiran institusi pesantren dalam perubahan dan pemberdayaan masyarakat

\footnotetext{
3 Suhartini, Problem Kelembagaan Pengembangan Ekonomi Pondok Pesantren, dalam A. Halim et. al. (eds.) Manajemen Pesantren (Yogyakarta: Pustaka Pesantren, 2005), hlm. 233.
} 
menjadi semakin kuat. Namun demikian harus diakui, belum semua potensi besar yang dimiliki pesantren tersebut dimanfaatkan secara maksimal, terutama yang terkait dengan kontribusi pesantren dalam pemecahan masalah-masalah sosial ekonomi umat.Pada batas tertentu pesantren tergolong di antara lembaga pendidikan keagamaan swasta yang leading, dalam arti berhasil merintis dan menunjukkan keberdayaan baik dalam hal kemandirian penyelenggaraan maupun pendanaan (self financing). Tegasnya selain menjalankan tugas utamanya sebagai kegiatan pendidikan Islam yang bertujuan regenerasi ulama, pesantren telah menjadi pusat kegiatan pendidikan yang konsisten dan relatif berhasil menanamkan semangat kemandirian, kewiraswastaan, semangat berdikari yang tidak menggantungkan diri kepada orang lain. ${ }^{4}$

Pengembangan ekonomi masyarakat pesantren mempunyai andil besar dalam menggalakkan wirausaha. Di lingkungan pesantren para santri dididik untuk menjadi manusia yang bersikap mandiri dan berjiwa wirausaha. ${ }^{5}$ Pesantren giat berusaha dan bekerja secara independent tanpa menggantungkan nasib pada orang lain atau lembaga pemerintah swasta. Secara kelembagaan pesantren telah memberikan tauladan, contoh riil (bi al-haal) dengan mengaktualisasikan semangat kemandirian melalui usaha-

${ }^{4}$ Habib Thoha, Kapita Selekta Pendidikan Islam (Yogyakarta: Pustaka Pelajar, 1996), hlm. 52.

${ }^{5}$ Wahjoetomo, Perguruan Tinggi Pesantren Pendidikan Alternatif Masa Depan, (Jakarta: Gema Insani Press, 1997), hlm. 95. 
usaha yang konkret dengan didirikannya beberapa unit usaha ekonomi mandiri pesantren. Secara umum pengembangan berbagai usaha ekonomi di pesantren dimaksudkan untuk memperkuat pendanaan pesantren, latihan bagi para santri, dan pemberdayaan mentalitas masyarakat dalam berwirausaha.

Perubahan dan pengembangan pesantren terus dilakukan, termasuk dalam menerapkan manajemen yang profesional dan aplikatif dalam pengembangannya. Karena istilah manajemen telah membaur ke seluruh sektor kehidupan manusia. ${ }^{6} \mathrm{Di}$ antara pengembangan yang harus dilakukan pesantren adalah pengembangan sumber daya manusia pesantren, pengembangan komunikasi pesantren, pengembangan ekonomi pesantren, dan pengembangan teknologi informasi pesantren.

Keterampilan kerja dan berkarya diharapkan mampu dimiliki oleh para santri, sehingga nantinya terbiasa mandiri dalam mencukupi kebutuhannya. Pendidikan keterampilan (ataupun berkarya) di pesantren hendaknya tetap tidak mengesampingkan pendidikan agama, karena pendidikan agama merupakan inti yang harus didalami dalam setiap pesantren. Kedalaman bidang agama akan mengantarkan santri untuk menjadi panutan kepada masyarakat muslim serta menata kehidupan tradisi yang bertentangan dengan ajaran agama Islam. Bidang ekonomi nantinya santri diharapkan mengawali dan tidak

6 Syamsudduha, Manajemen Pesantren: Teori dan Praktek (Yogyakarta: Grha Guru, 2004), hlm. 15-16. 
pernah mengajarkan pemisahan antara ibadah ritual dan kerja. Keduanya merupakan kewajiban setiap muslim, maka kerja merupakan salah satu bentuk jihad untuk memperoleh ketenangan dalam ibadah ritual. ${ }^{7}$

Pentingnya pengembangan entrepreneurship ini sebenarnya telah tergambarkan oleh realita saat ini, yang mengungkapkan bahwa Pendidikan kewirausahaan (entrepreneurship) di Indonesia masih kurang memperoleh perhatian yang cukup memadai, baik oleh dunia pendidikan, masyarakat, maupun pemerintah. Banyak praktisi pendidikan yang kurang memperhatikan aspek-aspek penumbuhan mental, sikap, dan prilaku kewirausahaan peserta didik, baik di sekolah kejuruan maupun profesional sekalipun. Orientasi mereka, pada umumnya hanya pada upaya-upaya menyiapkan tenaga kerja yang siap pakai. Sementara itu, dalam masyarakat sendiri telah berkembang lama kultur feodal (priyayi) yang diwariskan oleh penjajahan Belanda.

Sebagian besar anggota masyarakat memiliki persepsi dan harapan bahwa output dari lembaga pendidikan dapat menjadi pekerja (karyawan, administrator atau pegawai) oleh karena dalam Pandangan mereka bahwa pekerja (pegawai) adalah priyayi yang memiliki status sosial cukup tinggi dan disegani oleh masyarakat. Akan tetapi, melihat kondisi objektif yang ada, persepsi dan orientasi di atas harus diubah karena sudah tidak lagi

\footnotetext{
7 Nidhamun Mi'am, Dimensi Keberagaman Dan Keberhasilan Ekonomi Di Jepara, 1997. hlm 2 .
} 
sesuai dengan perubahan maupun tuntutan kehidupan yang berkembang sedemikian kompetitif. Pola berpikir dan orientasi hidup kepada pengembangan kewirausahaan merupakan suatu yang urgent untuk mulai dibangun.

\section{B. Manajemen Pesantren Entrepreneurship}

\section{Manajemen}

Manajemen berasal dari kata to manage : mengatur. Jadi manajemen itu merupakan suatu proses untuk mewujudkan tujuan yang diingini. Ada beberapa definisi manajemen, antara lain menurut Malayu Hasibuan, Manajemen adalah ilmu dan seni mengatur proses pemanfaatan sumber daya manusia (SDM) dan sumber lainnya secara efektif dan efisien untuk mencapai suatu tujuan tertentu. Andrew F. Sikula mengatakan Manajemen adalah Manajemen pada umumnya dikaitkan dengan aktivitas-aktivitas perencanaan, pengorganisasian, pengendalian, penempatan, pengarahan, pemotiva sian, komunikasi dan pengambilan keputusan yang dilakukan oleh setiap organisasi dengan tujuan untuk mengkoordinasikan berbagai sumber daya yang dimiliki oleh perusahan sehingga akan dihasilkan suatu produk / jasa secara efisien.

Mendefinisikan manajemen ada berbagai ragam, ada yang mengartikan dengan ketatalaksanaan, manajemen pengurusan dan lain sebagainya. Pengertian manajemen dapat dilihat dari tiga pengertia ${ }^{8} y a i t u$ manajemen, sebagai suatu

8 M. Manullang, Dasar Dasar Manajemen, (jakarta: Ghalia Indonesia,1983), hlm. 15-16 
proses, manajemen sebagai suatu kolektivitas manusia dan manajemen sebagai ilmu ( science) dan sebagai seni

Manajemen sebagai suatu proses. Pengertian manajemen sebagai suatu proses dapat dilihat dari pengertian menurut :

1. Encylopedia of the social science, yaitu suatu proses dimana pelaksanaan suatu tujuan tertentu dilaksanakan dan diawasi.

2. Haiman, manajemen yaitu fungsi untuk mencapai suatu tujuan melalui kegiatan orang lain, mengawasi usaha-usaha yang dilakukan individu untuk mencapai tujuan

3. Georgy R. Terry, yaitu cara pencapaian tujuan yang telah ditentukan terlebih dahulu dengan melalui kegiatan orang lain.

Manajemen sebagai kolektivitas yaitu merupakan suatu kumpulan dari orang-orang yang bekerja sama untuk mencapai suatu tujuan bersama. Kolektivitas atau kumpulan orang-orang inilah yang disebut dengan manajemen, sedang orang yang bertanggung jawab terhadap terlaksananya suatu tujuan atau berjalannya aktivitas manajemen disebut Manajer. Manajemen sebagai suatu ilmu dan seni, melihat bagaimana aktivitas manajemen dihubungkan dengan prinsip-prinsip dari manajemen. Pengertian manajemen sebagai suatu ilmu dan seni dari $:^{9}$

9 Oey Liang Lee, Pengertian Manajemen. (Jakarta: Balai Pustaka Administrasi ,UGM, 2010) , Bulletin no.1 
1. Chaster I Bernard dalam bukunya yang berjudul The function of the executive, bahwa manajemen yaitu seni dan ilmu, juga Henry Fayol, Alfin Brown Harold, Koontz Cyril O'donnel dan Geroge R. Terry.

2. Marry Parker Follett menyatakan bahwa manajemen sebagai seni dalam menyelesaikan pekerjaan melalui orang lain.

Berdasarkan definisi di atas dapat disimpulkan bahwa manajemen yaitu koordinasi semua sumber daya melalui proses perencanaan, pengorganisasian, penetapan tenaga kerja, pengarahan dan pengawasan untuk mencapai tujuan yang telah ditetapkan terlebih dahulu.Sedangkan pendidikan Islam, dari berbagai literatur mempunyai definisi yang variatif. Menurut Athiyah Al-Abrasy, pendidikan Islam adalah mempersiapkan manusia supaya hidup dengan sempurna dan bahagia, mencintai tanah air, sehat jasmaninya, sempurna budi pekertinya, pola pikirnya teratur dengan rapi, perasaannya halus, profesional dalam bekerja dan manis tutur katanya. Sedang Ahmad D. Marimba memberikan pengertian bahwa pendidikan Islam adalah bimbingan jasmani dan rohani berdasarkan hukum-hukum Islam menuju kepada terbentuknya kepribadian utama menurut ukuran-ukuran Islam. ${ }^{10}$ Sedangkan menurut Syed Muhammad Naquib Al-

10 Ahmad D Marimba, Pengantar Filsafat Pendidikan Islam, (Bandung: Al-ma'arif, 1978), hlm. 29 
Attas, pendidikan adalah suatu proses penamaan sesuatu ke dalam diri manusia mengacu kepada metode dan sistem penamaan secara bertahap, dan kepada manusia penerima proses dan kandungan pendidikan tersebut. ${ }^{11}$

Dari definisi dan pengertian itu ada tiga unsur yang membentuk pendidikan yaitu adanya proses, kandungan, dan penerima. Kemudian disimpulkan lebih lanjut yaitu " sesuatu yang secara bertahap ditanamkan ke dalam diri manusia". Jadi definisi pendidikan Islam adalah pengenalan, pembimbingan perlakuan secara berangsur-angsur yang ditanamkan ke dalam diri manusia, sehingga membimbing ke arah pengenalan dan pengakuan terhadap Tuhan. ${ }^{12}$ Jadi, berdasarkan ulasan diatas manajemen pendidikan Islam adalah sebuah cara dan seni dari sekelompok orang untuk mengatur dan membimbing pesesrta didik agar menjadi manusia yang dekat dengan tuhannya dalam bingkai sebuah lembaga.

\section{Fungsi Manajemen}

Fungsi manajemen menurut beberapa penulis antara lain :

a. Ernest Dale: Planning, Organizing, Staffing, Directing, Innovating, Representing dan Controlling.

b. Oey Liang Lee: Planning, Organizing, Directing, Coordinating, Controlling.

\footnotetext{
11 Kemas Badaruddin, Filsafat Pendidikan Islam. (Yogyakarta: Pustaka Pelajar, 2007), hlm. 36

12 Yusuf Al-Qardhawi, Pendidikan Islam dan Madrasah Hasan Al-Banna, terj. Prof. H. Bustami A. Gani dan Drs.Zainal Abidin Ahmad (Jakarta: Bulan Bintang, 1980)hlm.78
} 
c. James Stoner: Planning, Organizing, Leading, Controlling.

d. Henry Fayol: Planning, Organizing, Commanding, Coordinating, Controlling.

e. Lindal F.Urwich: Forescating, Planning, Organizing, Commanding, Cordinating, Controlling.

f. SP. Siagian: Planning, Organizing, Motivating, Controlling.

g. Prayudi Atmosudirjo: Planning, Organizing, Directing/ Actuating, Controlling.

h. Winardi: Planning, Organizing, Coordinating, Actuating, Leading, Communicating, Controlling.

i. The Liang Gie: Planning, Decision Making, Directing, Coordinating, Controlling, Improving.

Pada hakekatnya fungsi-fungsi di atas, dapat dikombinasikan menjadi 10 fungsi yang juga cocok digunakan dalam manajemen pendidikan Islam, yaitu :

a. Ramalan yaitu kegiatan meramalkan, memproyeksikan terhadap kemungkinan yang akan terjadi bila sesuatu dikerjakan.

b. Planning (perencanaan) yaitu penentuan serangkaian tindakan dan kegiatan untuk mencapai hasil yang diharapkan.

c. Organizing (organisasi) yaitu pengelompokan kegiatan untuk mencapai tujuan, temasuk dalam hal ini penetapan susunan organisasi, tugas dan fungsinya.

d. Staffing atau Assembling Resources (penyusunan personalia) 
yaitu penyusunan personalia sejak dari penarikan tenaga kerja baru. latihan dan pengembangan sampai dengan usaha agar setiap petugas memberi daya guna maksimal pada organisasi.

e. Directing atau Commanding (pengarah atau mengkomando) yaitu usaha memberi bimbingan saran-saran dan perintah dalam pelaksanaan tugas masing-masing bawahan (delegasi wewenang) untuk dilaksanakan dengan baik dan benar sesuai dengan tujuan yang telah ditetapkan.

f. Leading yaitu pekerjaan manajer untuk meminta orang lain agar bertindak sesuai dengan tujuan yang telah ditetapkan.

g. Coordinating (koordinasi) yaitu menyelaraskan tugas atau pekerjaan agar tidak terjadi kekacauan dan saling melempar tanggung jawab dengan jalan menghubungkan, menyatu-padukan dan menyelaraskan pekerjaan bawahan.

h. Motivating (motivasi) yaitu pemberian semangat, inspirasi dan dorongan kepada bawahan agar mengerjakan kegiatan yang telah ditetapkan secara sukarela.

i. Controlling (pengawasan) yaitu penemuan dan penerapan cara dan peralatan untuk menjamin bahwa rencana telah dilaksanakan sesuai dengan tujuan.

j. Reporting (pelaporan) yaitu penyampaian hasil kegiatan baik secara tertulis maupun lisan

\section{Manajemen soft skill Pesantren Entrepreneurship}


Soft skill merupakan materi pokok yang dikembangkan dilembaga pendidikan pondok pesantren. Oleh karena itu, agar menjadi sistematis maka ada aturan mainya menggunakan kaidah-kaidah ilmu manajemen. Berikut adalah penjelasan hasil penelitian lapangan yang penulis lakukan berdasarkan data yang diperoleh.

\section{Manajemen pengembangan soft skill of entrepreneurship.}

Manajemen adalah ilmu dan seni mengatur proses pemanfaatan sumber daya manusia dan sumber lainnya secara efektif dan efisien untuk mencapai suatu tujuan tertentu. Sebuah seni mengatur, mengelola supaya target tercapai secara efektif dan efisien. Manajemen pengembangan soft skill of entrepreneurship proses aktivitas pendidikannya secara urut dimulai dari perencanaan program, pengorganisasian program, pelaksanaan program dan yang terkahir adalah evaluasi program pembelajaran selama satu tahun pelajaran (satu angkatan).

a. Perencanaan Pengembangan Soft Skill of Entrepreneurship

Perencanaan adalah memilih dan menghubungkan fakta membuat serta menggunakan asumsi-asumsi mengenai masa datang dengan jalan menggambarkan dan merumuskan kegiatan-kegiatan yang diperlukan untuk mencapai hasil yang di inginkan. Hasil akhir sangat mungkin dapat terlihat dari perencanaan yang dipersiapkan sebelumnya. Para pengelola pesantren dapat menargetkan 
dan mengukur kualitas hasilnya dari perencanaan yang dibuatnya.

Dari data yang diperoleh di lapangan, penulis menemukan beberapa tahapan dalam perencanaan kurikulum pengembangan soft skill of entrepreneurship. Tahapan yang dimaksud adalah sebagai berikut:

b. Evaluasi kurikulum pengembangan softskill sebelumnya

Aktifitas manajemen tak ubahnya seperti sebuah lingkaran yang tak berujung. Perjalananya akan berputar ke titik awal kembali. Perencanaan yang ada diawal rangkaian juga akan melihat rangkaian terakhir sebelum memulai lagi. Begitu juga dengan rencana pembuatan konsep kurikullum soft skill entrepreneurship, para pengelola melakukan evaluasi tahun sebelumnya kemudian mengembangkannya lagi agar lebih sempurna.

Berdasarkan hasil wawancara dan beberapa data dokumentasi, dapat disimpulkan bahwa ada beberapa hal yang dievaluasi terkait dengan perencanaan kurikulum pengembangan soft skill of enterpreneurship, yaitu :

1) Isi kurikulum

2) Sumber daya manusia (pengelola yang mendapatkan amanah dibidangnya)

3) Tenaga penganjar

4) Fasilitas pendukung

5) Peserta didik 
6) Tahapan materi kurikulum

7) Tempat praktikum

8) Waktu pelaksanaan

9) Penjadwalan

c. Pembentukan Team Penyusun Kurikulum

Langkah ini adalah bentuk lanjutan dari kegiatan evaluasi kurikulum sebelumnya. Tim penyusun kurikulum dipilih oleh direktur berdasarkan hasil musyawarah pada evaluasi akhir tahun pembelajaran sebelumnya. PrinsipPrinsip Landasan Kurikulum.

Prinsip landasan pembuatan kurikulum pengembangan soft skill of entrepreneurship ini dijadikan sebagai acuan dan spirit yang ada dalam diri seorang entrepreneur muslim. Nilai-nilai yang diusung tersebut adalah sebagai berikut ${ }^{13}$ :

1) Nilai-nilai Tauhid

Santri harus memiliki kesadaran sebagai hamba dari Al Khaliq, makhluk dari Sang Pencipta, dan posisi manusia yang dibekali akal oleh Allah SWT., dilebihkan dari yang lain. Konskuensi dari kesadaran itu, setiap individu yang ada memiliki pemahaman bahwa setiap aktivitasnya diatur oleh yang Maha Mengetahui, yaitu Allah SWT. Dari pemahaman ini diharapkan pula santri-

13 Fadlullah, Pendidikan Entrepreneurship Berbasis Islam \& Kearifan Lokal, (Jakarta: Diadit Media Press, 2011), hlm76. 
santri yang dihasilkan memiliki landasan keimanan yang kuat yang dihasilkan/terlahir dari proses berpikir secara jernih dan mendalam. Dengan demikian maka tindakan-tindakan harian/perilaku sehari-hari akan mencerminkan dan dilandasi nilai-nilai keimanan/ tauhid sebagai penampakan pemahaman wajibnya terikat dengan aturan Sang Pencipta.

2) Ketaatan Yang Tinggi

Implikasi dari tingkat keimanan yang kuat dan keterikatan dengan syari'at Allah SWT adalah ketaatan yang tinggi. Baik ketaatan pada Allah SWT. seruan Rosul-Nya, maupun ketaatan pada pimpinan dan aturan di PERWIRA AbA. Ketaatan ini bisa dipahami sebagai wujud kepercayaan dan pengabdian seseorang kepada sesuatu yang diluar dirinya sesuai dengan aturanaturan Allah SWT. Dalam prakteknya, konsep ketaatan ini akan terwujud dalam kehidupan sehari-hari santri seperti ibadah, pakaian, tingkah laku, proses belajar mengajar, ujian, berinteraksi dengan sesama, dan lain lain.

3) Ukhuwah Islamiyah

Sifat khas dari kaum muslimin adalah tertanamnya semangat dan nilai-nilai ukhuwah Islamiyah yang tinggi pada mereka. Nilai-nilai ini juga akan ditanamkan pada santri sebagai wujud proses 
penyadaran bahwa mereka adalah bagian dari kaum muslimin yang harus mengetahui apa itu Ukhuwah dan Ukhuwah Islamiyah.Semangat Ukhuwah Islamiyah muncul dalam sikap saling membantu dalam kebenaran dan ketaqwaan dan tidak saling bantu dalam kejahatan dan dosa, serta saling nasehat menasehati dalam kebenaran dan kesabaran, mengoreksi sesama santri dan lapang dada pula apabila mendapat kritikan dari sesama

4) Kerja Keras

Santri diharapkan memiliki semangat untuk bekerja keras dan semangat pantang menyerah. Semangat ini perlu ditanamkan sejak dini sebagai upaya untuk mendidik para santri agar mereka siap untuk mengadapi realitas/kenyataan hidup di masa depan, tantangan-tantangan, hambatan-hambatan, dan segala macam problema hidup yang akan ditemui. Semangat ini dilandasi dari sirah Rosul dimana Rosul sangat senang dan memuji para shahabat yang telapak tangannya keras sebagai wujud kerja keras mereka. Jadi etos kerja harus menjiwai semangat hidup para santri.

5) Keilmuan

Sebagai seorang Muslim kewajiban yang tidak bisa ditinggalkan adalah mencari ilmu, baik ilmu yang berkenaan dengan pribadi, maupun ilmu yang berkenaan dengan masyarakat. Ilmu yang berkenaan 
dengan pribadi akan berguna jika seorang muslim akan menunaikan kewajiban yang berhubungan antara individunya dengan sang Pencipta. Sedang ilmu yang lain akan sangat berguna jika individu tersebut akan berinteraksi dengan masyarakat. Dengan kata lain sikap keilmuan ini harus menjiwai setiap santri. Untuk itulah Santri harus memiliki konsep-konsep dasar keilmuan yang cukup sebagai pilar rujukan dari masyarakat. Dalam hal keilmuan ini tentu tsaqafah Islam harus menjadi pemahaman yang lebih dari ilmu-ilmu yang lain. Artinya pemahaman tentang Tsaqafah Islam dalam segala aspek akan menjadi modal yang sangat potensial dan cemerlang untuk proses interaksi dan perubahan tatanan masyarakat sesuai syari'at Islam. Semangat membaca dan mutabaah harus terpantri dalam jiwa para santri.

6) Perjuangan dan Pengorbanan

Semangat yang tidak pernah lepas dari para shahabat Rosul adalah semangat juang dan semangat tempur yang tinggi dalam membela Islam. Semangat juang ini juga akan menjadi semangat para santri dalam kehidupan sehari-hari. Santri harus memilki kesadaran bahwa Islam memerlukan perjuangan, kerja keras dan pengorbanan. Semangat untuk berjuang juga ditanamkan dari sisi bahwa mereka akan terjun dengan 
kehidupan nyata yang sangat keras, jahiliyah, dan brutal, untuk itu para santri ditanamkan untuk selalu memiliki semangat perjuangan yang tinggi dan pantang menyerah.

\section{7) Keikhlasan}

Sebagai seorang muslim, sudah selayaknya seorang santri memiliki sifat-sifat yang mulia seperti yang pernah dicontohkan oleh Rosul SAW. Salah satu sifat yang selalu dicontohkan oleh Rosul adalah sikap ikhlas. Sikap ikhlas ini merupakan salah satu syarat supaya amal diterima oleh Allah SWT.

8) Kejujuran

Sifat dan karakteristik yang juga harus dimiliki oleh santri adalah sifat jujur. Jujur bukan semata-mata norma yang berlaku di masyarakat, namun sikap jujur yang memang dilandasi oleh perintah syara'. Sifat ini akan menanamkan persepsi dan pandangan pada masyarakat bahwa santri yang dihasilkan memang orang-orang yang memiliki sifat-sifat yang sesuai dengan pandangan Islam. Dari sikap ini akan muncul kepercayaan dari masyarakat, sikap simpati, dan kerjasama berlandaskan kejujuran sebagai salah satu landasan moral yang ada di masyarakat.

9) Kemandirian 
Santri dibekali dengan semangat dan tekad untuk memiliki kemandirian dalam hidupnya. Artinya dalam menghadapi segala permasalahan hidup sangat ditekankan untuk bersikap dan berbuat semaksimal dan seoptimal mungkin dengan kekuatan dan sumber daya sendiri. Selama santri sendiri mampu mengatasi maka diprioritaskan untuk diselesaikan dengan sumber dayanya sendiri. Sikap mandiri merupakan modal dasar bagi santri untuk sukses dalam berwirausaha apabila telah selesai masa pendidikan mereka.

10) Keteladanan

Apabila telah berbaur dan menyatu dengan masyarakat, maka yang dibutuhkan adalah istiqomah dan suri tauladan. Begitu bagi para santri, sikap untuk selalu istiqomah berpegang teguh dengan aturan Allah, dan mengaplikasikan dalam perbuatan sehari-hari akan memberikan citra positif di masyarakat. Keteladan ini perlu ditanamkan pada para santri, karena mereka adalah unsur dari masyarakat yang notabene memiliki pemahaman Islam yang cukup, dan telah dididik untuk menjadi uswah bagi masyarakat. Untuk itu, membaca dan mempelajari kisah-kisah hidup orang sukses merupakan salah satu kebiasaan yang harus ditanamkan pada diri santri

\section{Menentukan standar kompetensi lulusan}


Santri yang telah menyelesaikan pendidikan pada PERWIRA AbA ini diharapkan memiliki kualifikasi sebagai berikut ${ }^{14}$ :

a. Kepribadian Islam

Kepribadian Islam tersusun atas dua unsur yaitu pola pikir (aqliyah) dan pola sikap (nafsiah), maka kualitas kepribadian santri yang diharapkan adalah sebagai berikut:

1) Aqliah

Santri diharapkan memiliki pemahaman Islam yang akan menuntunnya untuk senantiasa berfikir Islami. Santri mampu memahami kejadian-kejadian kontemporer dengan kerangka pemahaman Islam

2) Nafsiah

Santri diharapkan memiliki nafsiah Islam, yaitu bertingkah laku sesuai dengan ajaran Islam yang merupakan perwujudan ketaatan terhadap ajaran Islam dalam aspek ibadah, makanan, minuman, akhlak, muamalah, aqidah, syari'ah, dan dakwah, serta fiqih kontemporer.Memiliki kemampuan pendukung seperti Bahasa Arab, hafal Al-Qur'an minimal hafal ayat-ayat pilihan, hafal 40 hadits pilihan.Memiliki kemampuan untuk memberikan materi keislaman baik dalam bentuk ceramah maupun khotbah

${ }^{14}$ Hasil dokumentasi dari prinsip-prinsip kurikulum PERWIRA ABA, 
b. Profesionalisme

Santri memiliki syarat-syarat kapabilitas yang memadai untuk menjalankan usaha secara profesional.

1) Santri memiliki etos kerja yang tinggi

2) Santri memiliki sikap yang amanah dalam menjalankan tanggung jawab

3) Santri mampu menyusun perencanaan usaha.

4) Santri mampu menyusun kelayakan usaha atau proposal usaha sesuai dengan standar lembaga keuangan.

5) Santri mampu memecahkan masalah dengan sistematis

6) Santri memiliki kemampuan merencanakan dan menerapkan sistem pembukuan dan analisa keuangan sederhana.

7) Santri mampu menjalin hubungan dengan berbagai pihak untuk kepentingan bisnis dan kepentingan umat.

8) Santri memiliki kemampuan dasar tentang komputer dan mampu mengaplikasikannya dalam usaha termasuk bisnis usaha di internet.

9) Santri memiliki ketrampilan untuk transaksi sehingga mampu menghasilkan pendapatan setara dengan tiga kali UMR daerah.

c. Kemandirian

Santri memiliki kemampuan dasar manajemen dan kepemimpinan yang aplikatif, yang akan mendorongnya untuk bersikap mandiri dalam penerapan prinsip 
perencanaan, pengorganisasian, pelaksanaan, dan pengontrolan kegiatan.

1) Santri memiliki kebiasaan hidup disiplin, tertib, rapi dan teratur

2) Santri memiliki kepercayaan diri yang tinggi.

3) Santri mampu mengukur potensi diri, memformulasikan visi diri, dan mengembangkan potensi diri.

4) Santri mampu bertindak dan bersikap sebagai seorang wirausaha yang siap untuk berkarya.

5) Santri mampu membaca peluang usaha, mengelolanya dan memasarkan atau menjualnya ke konsumen.

6) Santri memiliki kemampuan dasar untuk menjalankan usaha secara mandiri.

7) Santri memiliki keberanian untuk memulai dan menjalankan usaha dalam situasi dan kondisi apapun.

d. Moslem Entreprepreneur Mind Setting

Entrepreneur merupakan seseorang yang melakukan kegiatan wirausaha yang mampu memasarkan, mengembangkan serta mampu mengatur jalannya usaha itu agar dapat bertahan lama dan dapat terus mengeluarkan ide-ide serta inovasi terbaru melalui perkembangan zaman. Menurut para ahli, arti dari entrepreneur adalah: pertama, menurut Thomas $\mathrm{W}$ Zimmerer pengertian entrepreneur adalah penerapan kreativitas dan keinovasian untuk 
memecahkan permasalahan dan upaya memanfaatkan peluang-peluang yang dihadapi orang setiap hari ${ }^{15}$.

Kedua, Peter F Drucker mendefinisikan pengertian entrepreneur adalah Kkemampuan untuk menciptakan sesuatu yang baru dan berbeda, bahasa kerennya ability to create the new and different. Ketiga, menurut Kasmir pengertian entrepreneur adalah orang yang berjiwa berani mengambil resiko untuk membuka usaha dalam berbagai kesempatan dan terakhir, menurut Soeparman Spemahamidjaja pengertian entrepreneur adalah suatu kemampuan (ability) dalam berfikir kreatif dan berperilaku inovatif yang dijadikan dasar, sumber daya, tenaga penggerak tujuan, siasat kiat dan proses dalam menghadapi tantangan hidup.

Seorang entrepreneur harus dapat mengatur pola pikirnya atau yang biasa disebut dengan mindset. Mindset untuk seorang entrepreneur harus ditanamkan sejak dini karena mindset merupakan salah satu hal penting bagi seorang entrepreneurship yang membuat seseoranng dapat suksess. Mindset awal yang harus dimiliki oleh seorang entrepreneur yang pertama adalah berfikir Positif 16 , dengan berfikir positif, kita dapat membentuk kepercayaan diri kita serta dapat mengetahui kualitas dari diri sendiri untuk

\footnotetext{
${ }^{15}$ http:/ / bbs.binus.ac.id/business-creation/2017/03/mindset-yang-harus-dibangu n-oleh-seorang-pengusaha/

16 https://www.scribd.com/doc/35176101/Entrepreneurial-Mindset
} 
membangun sebuah motivasi agar dapat lebih berkembang. Dengan berfikir positif dapat membuat kita fokus untuk mencapai sebuah tujuan agar dapat melewati rintanganrintangan untuk menuju kesuksessan.kedua adalah bertanggung jawab dengan keputusan yang diambil dimana seorang entrepreneur memiliki kesempatan untuk menciptakan banyak inovasi-inovasi baru tanpa memikirkan hal-hal yang dapat merugikan suatu perusahaan. Mindset inilah yang harus diubah dari seorang entrepreneur. Karena, seorang entrepreneur harus bertanggung jawab terhadap segala aspek yang terkait dengan usahanya, serta kesejahterahan usaha dan timnya.

Tidak ada seorang pengusaha yang langsung suksess ketika merintis sebuah bisnis. Dengan memiliki semangat untuk maju dan sikap pantang menyerah kita dapat melewati banyak rintangan-rintangan yang menghadang dan dapat mencapai tujuan yang ingin dicapai. Keempat adalah Siap dan berani untuk gagal, Semua orang yang telah suksess pasti pernah merasakan yang dinamakan dengan kegagalan. Untuk memulai suatu bisnis janganlah takut akan kegagalan serta kerugian yang akan didapatkan, karena itu semua adalah hal-hal awal untuk mencapai kesuksessan. Cara untuk meminimalisir kegagalan adalah mau belajar dari kesalahan serta kritikan dari orang luar, jangan pernah mengulangi kesalahan yang sama untuk 
kedua kalinya dan yang terakhir adalah memiliki komitmen atau tekad yang kuat, untuk memulai sesuatu kita harus memiliki komitmen serta tekad yang kuat agar kita dapat fokus pada satu tujuan yang ingin dicapai. Dengan memiliki komitmen yang kuat kita dapat mencapai tujuan dengan mudah serta kita dapat bersikap lebih professional dalam mengerjakan atau menjalankan usaha agar dapat lebih berkembang,

Mindset atau cara berfikir merupakan cara atau langkah dasar yang akan membawa kita kepada tujuan, impian ataupun goal besar yang ingin kita capai. Mulailah merubah pola pikir kita dari yang salah menjadi yang lebih baik, berfikir positif dan percaya bahwa kita bisa melakukan hal yang kita inginkan dan jangan pantang menyerah untuk mencapai kesuksessan

Entrepreneur yang memiliki modal kecakapan berfikir kreatif, akan secara nyata menghasilkan karya-karya yang kreatif jika memiliki sikap, motivasi, minat, keperibadian, dan kebiasaan-kebiasaan dalam berprilaku yang mendukung. Kewirausahaan pada awalnya muncul dari penemuan IPTEK yang dimanfaatkan oleh orang yang mampu menjual dan memasarkan inspirasi dan penemuan tersebut menjadi sebuah bisnis. Kemudian berubah dari menawarkan manfaat penemuan menjadi manfaat informasi penemuan-penemuan yang terjadi dalam bentuk iklan dan 
seterusnya. Kemudian berubah lagi dengan menciptakan suatu konsep terpadu untuk memenuhi kebutuhan, keinginan dan harapan orang-orang yang beragam. Jadi kewirausahaan telah bergesar dari menciptakan manfaat (creator as an Entrepreneur) dari sesuatu yang belum ada (create something from nothing) menjadi meningkatkan sesuatu yang sudah ada menjadi bernilai tambah (create something new from something) untuk memenuhi kebutuhan pasar; serta merubah pola persaingan, trand stter, change driver, dan innovator (innovator as an entrepreneur). ${ }^{17}$.

\section{Kesimpulan}

Pesantren adalah salah satu lembaga pendidikan Islam dengan kemampuan beradaptasi terhadap segala konteks kekinian. Lemabaga ini berperan sebagai penyangga pondasi keagamaan juga menghadirkan solusi problem kekinian dengan menempatkan ciri pembekalan entrepreneurship. Penulis menemukan urgensi manajemen dalam pengembangan soft skill entrepreneurship menjadi penentu keberhasilan visi membentuk satripreneur dari lulusan pesantren. Kedua, Pembangunan mental kewirausahaa (Soft skill of entrepreneurship), saja tidak cukup jika tidak ada penanaman secara spiritual. Ketiga, awal dari perencanaan dan manajemen kurikulumm entrepreneurship adalah Moslem Entepreneur Mind Setting (Merombak mind set

17 Fadlullah, Pendidikan Entrepreneurship Berbasis Islam \& Kearifan Lokal, (Jakarta: Diadit Media Press, 2011), hlm. 80 
masing-masing peserta didik bahwa sukses adalah hak setiap orang. 


\section{DAFTAR PUSTAKA}

Cooper, Robert K., The Other 90\%: How To Unclock Your Vast Untapped Potential for Leadership and Life, Elka Ferani, dkk (penj.). Bandung, Mizan, 2007.

Kementrian Pendidikan Nasional (Kemendiknas), Bahan Pelatihan dan Penggembangan Pendidikan Kewirausahaan, Jakarta : Kemendiknas Badan Penelittian dan Pengembangan kurikulum, 2010.

Ali, HA. Mukti, Beberapa Masalah Pendidikan Di Indonesia, Yogyakarta: Yayasan Nida, 1971.

Anorga, Panji dan Joko Sudantoko, Koperasi: Kewirausahaan dan Penguasaha Kecil Jakarta : Rineka Cipta, 2002.

Arikunto, Suharsimi, Prosedur Penelitian suatu Pendekatan Praktek Jakarta : Rineka Cipta, 1999.

As'ary, Musa, Agama dan Etos Kerja, dalam Al-Jami'ah No. 57 tahun Yogyakarta : IAIN Sunan Kalijaga, 1994.

Asmani, Jamal Ma'ruf, Sekolah life skill-Lulus Siiap Kerja!, Yogyakarta : Diva Press, 2009.

Azra, Prof.Dr.Azyumardi, Pendidikan Islam: Tradisi dan Modernisasi Menuju Milenium Baru, Penerbit Kalimah, Jakarta 2001

Billah, M.M., Pikiran Awal Pengembangan Pesantren, dalam Pergulatan Dunia Pesantren, Dawam Raharjo (ed), Jakarta: P3M, 1985.

Ciputra, Quantum Leap Entrepreneur, Jakarta: Exelmedia, 2008

Dedy Mulyana, Metodologi Penelitian Kualitatif : Paradigma baru Ilmu Komunikasi dan Ilmu sosial lainnya. Bandung : PT. Remaja Rosdakarya, 2002. 
Dunn, William N., Analisa Kebijakan Publik (terj), Public Policy Analiisys, Dr. Muhajir Darwin (penj), Hanindita, 1995.

Echols, John M. dan Hasan Shadili English-Indonesia, (Jakarta: Pustaka Utama), 2000.

Farchan, Hamdan dan Syarifuddin. Titik Tengkar Pesantren Resolusi Konflik Masyarakat Pesantren. Yogyakarta: Pilar Religia,2005.

Hasbullah, Drs., 1999, Sejarah Pendidikan Islam di Indonesia:Lintasan Sejarah Pertumbuhan dan Perkembangan, PT Raja Grafindo Persada, Jakarta, (hl 24-27, 138-161)

Hendro dan Candara, Be A Smart And Good Entrepreneur, Jakarta : Universitas Bina Nusantara, t.t.

Irianto, Yoyon Bahtiar, Kebijakan Pembaharuan Pendidikan :Konsep, teori, dan Model, Jakarta : PT. Rajagrafindo Persada, 2011.

Kafrawi, Pembaharuan sisitem pendidikan pondok pesantren sebagai usaha peningkatan prestasi kerja dan pembinaan kesatuan bangsa, Jakarta : Cemara Indah, 1978.

Kasali, Rhenald, Re-Code Your Change DNA, Jakarta: Gramedia, 2007.

Lutfieady, Ach., Ekonomi Pesantren (study atas kegiatan usaha Ekonomi Pesantren Al-Amin Prenduan Sumenep). Tesis, Muamalat,UIN Snan Kalijaga, 2004.

Madjid, Nurcholish, Bilik-Bilik Pesantren Sebuah Potret Perjalanan Jakarta: Paramadina, 1997

Ahsan, M. Azmi, Pesantren dan Pemberdayaan Ekonomi Umat (Studi ide dan kebijakan pendidikan di Pesantren Wirausaha Agrobisbis Abdurahman bin Auf Wonosari Klaten). Tesis, MKPI UIN Sunan Kalijaga Yogyakarta, 2004. 